\begin{tabular}{|l|l|l||}
\hline \multicolumn{2}{|c|}{ PublisherInfo } \\
\hline \hline PublisherName & $:$ & BioMed Central \\
\hline \hline PublisherLocation & $:$ & London \\
\hline \hline PublisherImprintName & $:$ & BioMed Central \\
\hline \hline
\end{tabular}

\title{
Musical protection
}

\begin{tabular}{|l|l|l||}
\hline \multicolumn{2}{|c|}{ ArticleInfo } \\
\hline \hline ArticleID & $:$ & 4420 \\
\hline \hline ArticleDOI & $:$ & $10.1186 /$ gb-spotlight-20020312-01 \\
\hline \hline ArticleCitationID & $:$ & spotlight-20020312-01 \\
\hline \hline ArticleSequenceNumber & $:$ & 86 \\
\hline \hline ArticleCategory & $:$ & Research news \\
\hline ArticleFirstPage & $:$ & 1 \\
\hline \hline ArticleLastPage & $:$ & 2 \\
\hline \hline & & RegistrationDate : 2002-3-12 \\
\hline ArticleHistory & $:$ & OnlineDate \\
\hline \hline ArticleCopyright & $:$ & BioMed Central Ltd2002-3-12 \\
\hline \hline ArticleGrants & $:$ & \\
\hline \hline ArticleContext & $:$ & 130593311 \\
\hline \hline
\end{tabular}




\section{Jonathan B Weitzman}

Email: jonathanweitzman@hotmail.com

There has been much debate about whether DNA sequences may, or should, be patented. This issue has prevented the release and dispersal of much genomic data by commercial genomics companies. In the March issue of Nature Biotechnology, Willem Stemmer of Maxygen Inc. in California, offers a harmonious solution for the sharing of DNA sequences while maintaining intellectual property (IP) protection (Nature Biotechnology 2002, 20:217). While the patentability of DNA is in question, music and original creative works can be protected by copyright. Patent protection lasts for 17 years, whereas copyright protection may last up to 100 years. Stemmer proposes that companies encode their sequence data by transforming them into music files (for example in MP3 format) using existing Bio2MIDI programs. This 'musical DNA' could be copyright-protected and shared with external database users. The MP3 file would then be converted back to sequence information by a back-translation program. This proposal offers a way for companies to be more in tune with the academic genomic community.

\section{References}

1. Nature Biotechnology, [http://www.nature.com/nbt/]

2. Maxygen Inc., [http://www.maxygen.com]

3. Algorithmic ArtsTM, [http://geneticmusic.com/] 